\title{
インターバルカメラを用いたオオキンケイギクの開花量の推定方法
}

\section{Method for Estimating the Flowering Amount of Coreopsis lanceolata Using Time-lapse Camera}

\author{
小栗 ひとみ* 畠瀬 頼子*, ** 松江 正彦*** 栗原 正夫*
}

Hitomi OGURI Yoriko HATASE Masahiko MATSUE Masao KURIHARA

\begin{abstract}
The removal of Coreopsis lanceolate that was designated an invasive alien species have been attempted in river levees. However, in some cases, due to that it is not the best timing to perform the herbicide, there is also a risk of spreading the habitat not only to achieve the effect of the control. For full effectiveness, it is necessary to know the exact timing of flowering and fruiting of $C$. lanceolate in the region. Therefore, we have studied a method to understand quantitatively the amount of flowering, by analyzing the images captured using a time-lapse camera. Image analysis was performed in two ways, bloom color extraction and calculation of GRVI(Green-Red ratio Vegetation Index). Flowering color extraction results were in good agreement with the trends in the number of flower heads. As a result, we have confirmed that to shoot consecutive images by time-lapse camera, is an effective technique that can substitute for field measurement of the number of flowering.
\end{abstract}

Keywords: Coreopsis lanceolata, time-lapse camera, image analysis, flowering amount キーワード: オオキンケイギク, インターバルカメラ, 画像解析, 開花量

\section{1.はじめに}

特定外来生物オオキンケイギク (Coreopsis lanceolate) につい ては, 平成 3 年より 5 年に 1 回の頻度で実施されている河川水辺 の国勢調査において，確認河川および確認地区の割合が経年的に 増加し，分布が拡大していることが報告されている 1)。一方，河 川における防除の取り組みは，平成 18 年 2 月の国土交通大臣を 主務大臣等とする防除の公示を踏まえ，除草等の河川管理行為を 「特定外来生物による生態系等に係る被害の防止に関する法律」

第 11 条に基づく防除と位置付けた対策が進められている 2)。 河川の維持管理における除草は，堤防の強度保持や状態把握の ために，出水期前と台風期の点検に支障が生じないよう，概ね25〜 7月頃と $8 \sim 10$ 月頃の年2回, 機械による刚り取りを基本として実 施されている3）刈り取りによる管理では, 株そのものを除去する 効果は低いものの, 結実前に刈り取りを行えば, 種子の拡散を防 止することができる4)。堤防延長は極めて長大であるため，延長に 沿って順次刚り取りを進めていく場合，区間によっては管理適期 を逸してしまう可能性がある。管理時期が結実後となった場合に は，除草作業中や運搬時に，拡散を助長してしまうことにもなり かねない。より効果的，効率的な防除を行うためには，当該地域 におけるオオキンケイギクの開花結実の時期を正確に把握し，そ れを踏まえた作業工程の設定が重要である。

オオキンケイギクは全国的に逸出している5)。開花結実の時期は 気候に影響を受けており，南北に長い日本では開花結実の時期は 大きく異なる。そのため刈り取りに効果的な時期も異なるものと 予想される。広域で刚り取り時期を推測するためには，気候と開 花結実の時期の関係を定量的に知る必要があるが，広域において 連続的な開花結実のデータを, 現地調査によって定量的に得るに は, 多大な労力が必要となる。インターバルカメラを用いて自動 撮影した画像を解析することで，開花結実の推移を定量的に捉え ることができれば，広域にわたるデータを低コストで効率的に取 得することが可能となる。
インターバルカメラを利用した調査手法については, GRVI值と 植生や地表の季節变化の関係を解析した研究6)や, 湿原環境におけ る植生や生物季節の変化追跡を行った研究7)があり, その有効性が 示唆されている。環境省のモニタリングサイト 1000 における高山 帯の調査でも，開花フェノロジ一の調査方法として採用されてお り8)，オオキンケイギクの開花量の把握においても有効なツールと なりうる。ただし，全国の河川管理の現場において汎用的に使用 するには, より安価で簡便に使えることが不可欠である。そこで, インターバルカメラの中でも，より汎用性の高いツールを用いて, 連続撮影した画像からオオキンケイギクの開花量の推移を定量的 に把握する手法について検討を行い，頭花数の現地計測との比較 によりその有効性を検証した。

\section{2. 調査方法}

\section{（1）インターバルカメラによる連続撮影}

調査対象地は，才オキンケイギクの生育が確認されている国の 直轄河川の中から, 気温条件の異なる岩木川（青森県弘前市駒越 地先および青森県板柳町板柳地先），鬼怒川（杤木県さくら市氏 家地先），木曾川（岐阜県各務原市川島笠田町地先）の 3 河川の 高水敷とした（表一 1$)$ 。各河川のオオキンケイギク生育地に, インターバルカメラ 2 台および $1 \mathrm{~m} \times 1 \mathrm{~m}$ 調査区 5 区 (生育数が少

\section{表-1 調査対象河川の諸元}

\begin{tabular}{|c|c|c|c|c|c|c|}
\hline 河川名 & 調査対象地 & 緯度 & 経度 & $\begin{array}{c}\text { 標高 } \\
(\mathrm{m})\end{array}$ & \begin{tabular}{|c|} 
暖かさの \\
指数 \\
(WI)
\end{tabular} & $\begin{array}{l}\text { クライ } \\
\text { メイト } \\
\text { ゾーシ }\end{array}$ \\
\hline \multirow{2}{*}{ 岩木川 } & 青森県弘前市駒越地先 & 40.609 & 140.448 & 33.0 & \multirow{2}{*}{85.1} & \multirow{2}{*}{$8 b$} \\
\hline & 青森県板柳町板柳地先 & 40.694 & 140.454 & 12.0 & & \\
\hline 鬼怒川 & 栃木県さくら市氏家地先 & 36.676 & 139.950 & 161.0 & 114.5 & $9 a$ \\
\hline 木曽川 & 岐阜県各務原市川島笠田町地先 & 35.373 & 136.824 & 17.0 & 133.8 & $9 b$ \\
\hline
\end{tabular}

WI およびクライメイトゾーンは, 青森地方気象台, 宇都宮地方気象台および 岐阜地方気象台の 2005 2009 年における各月の平均気温ならびに最低気温 データを用いて算出した。

*国土交通省国土技術政策総合研究所 $* *$ 一般財団法人自然環境研究センター ***神奈川県（前 国土交通省国土技術政策総合研究所） 
なかった岩木川は 2 区）を設置した。インターバルカメラは，汎 用性の高いカメラとして，環境省のモニタリングサイト 1000 等 で実績のあるBrinno社製Garden Watch Camを使用した。また, インターバルカメラは, 調査区もしくは調查区近傍の範井で, で きるだけ多くのオオキンケイギクの個体が，個々の花が識別でき る範囲で写り込むよう位置を調整し，撮影間隔 2 時間で頭花の連 続撮影を行った（図一-1)。なお，調査地点の決定に際し河川管理 者との協議を要したため, 撮影開始時期が岩木川は平成 22 年 7 月 1 日，鬼怒川は平成 22 年 6 月 2 日，木曽川は平成 22 年 5 月 16 日と異なっているが，いずれも平成 22 年 8 月 31 日まで撮影 を継続した。

\section{(2) 頭花数の計測}

$1 \mathrm{~m} \times 1 \mathrm{~m}$ 調査区において,「未開花」「「開花」「「開花終了(初期)」 (花弁がしおれ，花弁の色が濃い黄色に変色したもの)，「花弁な し」の分類により，頭花数を計測した。調査は，平成 22 年 6 月 〜 月にかけて， 1 週間に 1 回の割合で，岩木川は 7 回，鬼怒川 は 11 回，木曽川は 10 回実施した。

\section{(3) 開花画像の解析}

インターバルカメラの画像データセットごとに，才オキンケイ ギクが一様に開花している範囲を切り出し，GRVI（Green-Red ratio Vegetation Index）の算出および開花色の抽出の 2 通りの方 法を用いて画像解析を実施した。解析の手順を図一2 に示す。

解析対象画像数は，岩木川 71 枚，鬼怒川 143 枚，木曽川 170 枚であった。前処理として, AVI 形式で記録された連続画像の中 から各日で最も撮影状態の良い画像を選び (図-3), JPEG 形式 に変換した後，解析対象範囲の切り出しを行い，解析用画像を作 成した。対象範囲の切り出しは，才オキンケイギク以外の地物な どの影響を排䣄する目的で行い，切り出し面積はインターバルカ メラごとに一定とした。また，天候の違い等による明るさのバラ ツキを補正するため, Adobe Photoshop により輝度の平均值を 256 階調の中央值付近に調整することによって標準化を行った。

解析手法として用いた GRVI は，主に衛星リモートセンシング データの解析に用いられる分光指数の一種で， 2.1 式により算出 される ${ }^{6), 9)}$ 。-1〜1 の值をとり, 紅葉などの葉色の変化を把握し やすい6)。算出には, ArcGIS 9.3 Spatial Analyst のラスタ演算 機能を用い, GRVI の統計量（平均值，標準偏差，最大值，最小 值)を求めた。

$\mathrm{GRVI}=($ Band2 - Band1 $) /($ Band2 + Band1 $)(2.1)$

ただし, Band1 は赤色光の反射率, Band2 は緑色光の反射 率を示す。ここでは, JPEG 画像が保持する RGB の 3Bannd のうち, Band1 (Red), Band2 (Green) を用いた。

また，開花色の抽出では，Adobe Photoshop の自動選択ツール を用いて開花色エリアを画面 上で選択し，選択された範囲 を黒色, それ以外の範囲を白 色に二值化して, 各画像の全 ピクセル数に占める開花色エ リアのピクセル数の割合 (開 花色面積率) を算出した。

\section{（4）解析手法の有効性の検} 証

画像解析によって求められ たGRVI 平均值および開花色 面積率について, 誤差分布と してポアソン分布を仮定し, 説明変数に一方は GRVI を, 他方は開花色面積率を用いて, リンク関数を”log”とする一
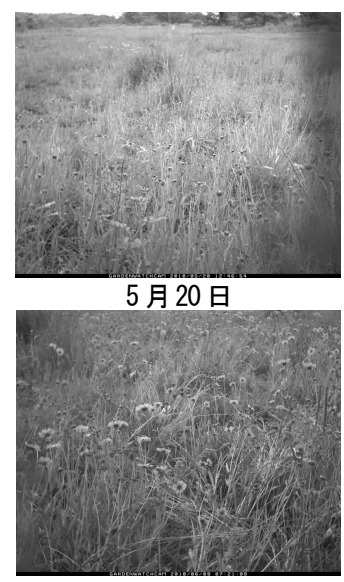

6 月 9 日
般化線形モデル（GLM）10)を 2 種類作成した。また, 調査方法が 3 つのブロック (河川) に各 2 台のカメラを固定し, 繰り返し撮 影を行うといらネスト構造 (入れ子型の階層構造) をとることか ら, 説明変数にネスト構造を表す項（河川/カメラ/ GRVI あるい は開花色面積率）を加えたモデルも同様に作成した ${ }^{11)}$ 。いずれの モデルも，目的変数は，河川ごとに記録された全頭花数とした。 ただし, 頭花数を求めた際の調査地点数が河川間で異なるため, 調查地点数の対数をオフセット項として加え, 補正を行った ${ }^{10)}$ 。 次に, このようにして作成した 4 種類のモデル $(\mathrm{GRVI}$ ・開花色 面積率×ネス卜構造の考慮あり・なし）の中から最も当てはまり

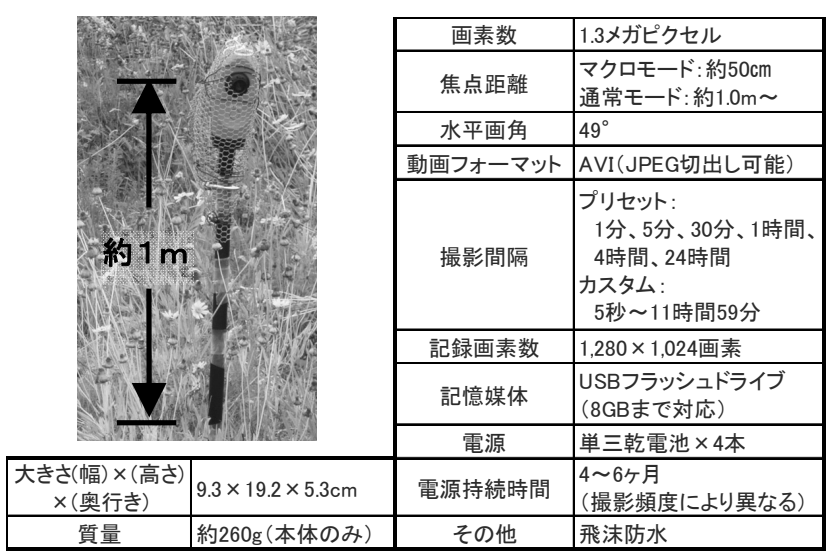

図ー1 インターバルカメラの諸元および設置状況

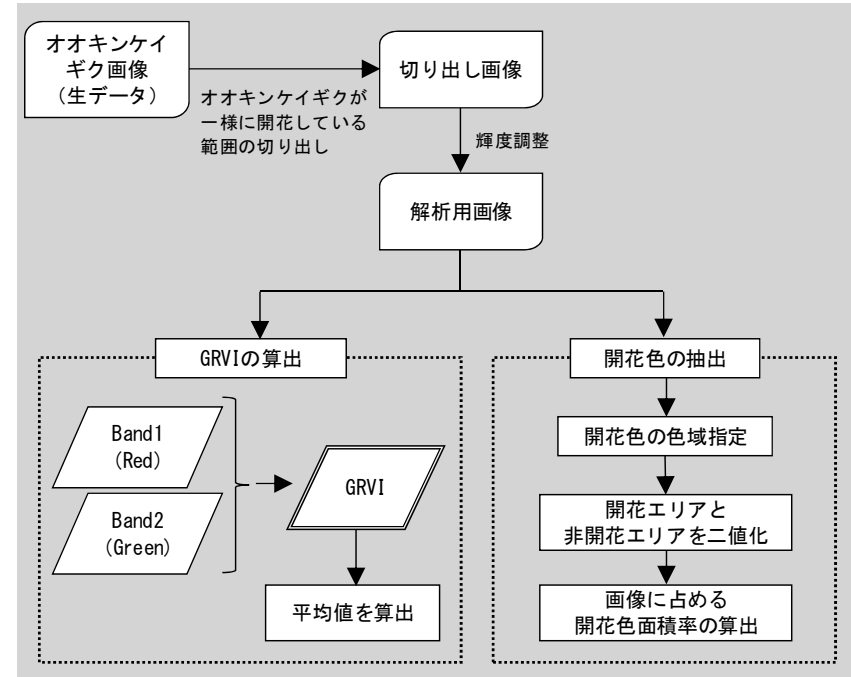

図-2 画像解析の手順

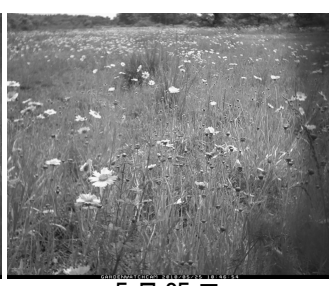

5 月 25 日

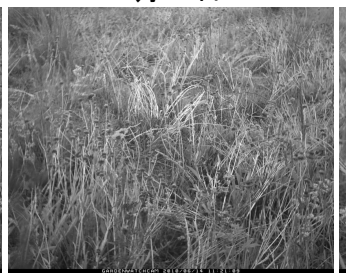

6 月 14 日

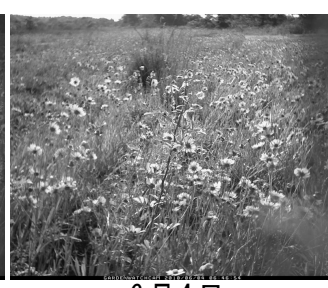

6 月 4 日

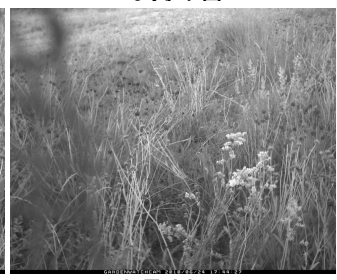

6 月 24 日

木曽川で 5 月 20 日〜 6 月 24 日に撮影された画像を 5 日間隔で並べた例。 
のよい説明変数の組合せを探るために, AIC (赤池情報量基準) 12)を用いたモデル選択を行った。これにより，GRVI と開花色面 積率のいずれが，頭花数を予測する指標として当てはまりが良い のかを判断した。最後に，モデル選択によって得られた最も当て はまりの良いモデル (ベストモデル) には，ネスト構造を表す項 が含まれていたことから, 計 6 台のカメラでの調査結果それぞれ についてポアソン回帰分析を行い，結果を比較した。これらの解 析には，統計解析ソフト $\mathrm{R}$ ver.2.15.2 を用いた ${ }^{13)}$ 。

\section{3. 結果}

（1）GRVI 平均値, 開花色面積率および平均頭花数の推移

河川ごとの GRVI 平均值，開花色面積率および全調査区の平均 頭花数の推移は，図-4のとおりである。

岩木川での GRVI 平均值は， 7 月 1 日および 7 月 8 日にピー クを示した後，変動を繰り返しながら緩やかに減少した。最低值 は8月 8 日であったが，その後も上昇，下降を繰り返す結果とな つた。一方，開花色面積率は， 7 月 1 日にピークを示した後急速 に減少し， 7 月 10 日には $1 / 4$ 程度の值となった。その後も緩やか に減少し, 平均頭花数の推移傾向と概ね対応寸る結果を示した。

なお，GRVI は赤・黄系統の色が強いほど值が低くなり，逆に 開花色面積率は黄色の開花が多いほど值が高くなる。したがって, 両者の推移は，才オキンケイギクの開花期から結実期にかけて対 照的な傾向を示寸ものと考えられるが，岩木川ではそのような傾 向は認められなかった。

鬼怒川の GRVI 平均值は， 6 月中旬までは 0.05〜0.1 程度の值 を示し，それ以降はやや高い $0.1 〜 0.2$ 程度で推移した。最低值は 6 月 9 日, 最高值は 7 月 16 日であった。一方, 開花色面積率は, 撮影開始から急激に増加し，6月 9 日に最大に達した後，急激に 低下しており，平均頭花数の推移傾向とよく対応する結果となっ た。鬼怒川においては, GRVI 平均值は盛花期に低い值を示し, 開花終了につれて值が高くなったが，開花色面積率は盛花期に高 い值を示し，開花終了につれて值が低くなるといつた対照的な傾 向を示した。

木曽川の GRVI 平均值は, 5 月下旬から 6 月上旬に $0 \sim 0.1$ 程度 の值を示し, 6 月中旬以降はやや高い $0.1 \sim 0.15$ 程度で推移した。 最低值は 6 月 3 日，最高值は 5 月 24 日であった。一方，開花色 面積率は，5月 22 日頃から急激に増加して 6 月 3 日に最大に達 した。その後, 急激に低下して 6 月中旬には 0 に近い值で横ばい となり, 平均頭花数の推移傾向とよく対応する結果となった。木 曽川においても，GRVI 平均值と開花色面積率との関係は，鬼怒 川同様対照的な傾向となった。

\section{（2）解析手法の有効性の検証}

頭花数の予測には，GRVI を説明変数に含むモデルに比べて開 花色面積率を説明変数に含むモデルの方が当てはまりが良く, AIC が最小となるベストモデルには開花色面積率とネスト構造 を表す項 (河川/カメラ/開花色面積率) が含まれていた (表一2)。 次に，カメラごとにポアソン回帰分析を行った結果，いずれのカ メラで撮影した場合にも，開花色面積率が高いほど頭花数も有意 に多いことがわかった（表一 3 ，図一5）。

\section{4. 考察}

\section{（1）画像解析手法の有効性亡限界}

オオキンケイギクの開花量を把握する手法として, 開花色の抽 出による面積率の算出が有効であることを確認した。今回の画像 解析で用いた方法は, Adobe Photoshop 等の一般的な画像編集ソ フトを利用したものであることから汎用性も高い。

一方，GRVI を用いた方法では，オオキンケイギクの開花量を 説明できない結果となった。その原因として，画像の全体的な色
調にむらがあったことや, 画像の切り出し面積に占めるオオキン ケイギクの開花エリアの面積割合が, 最大でも $48 \%$ 程度にとどま
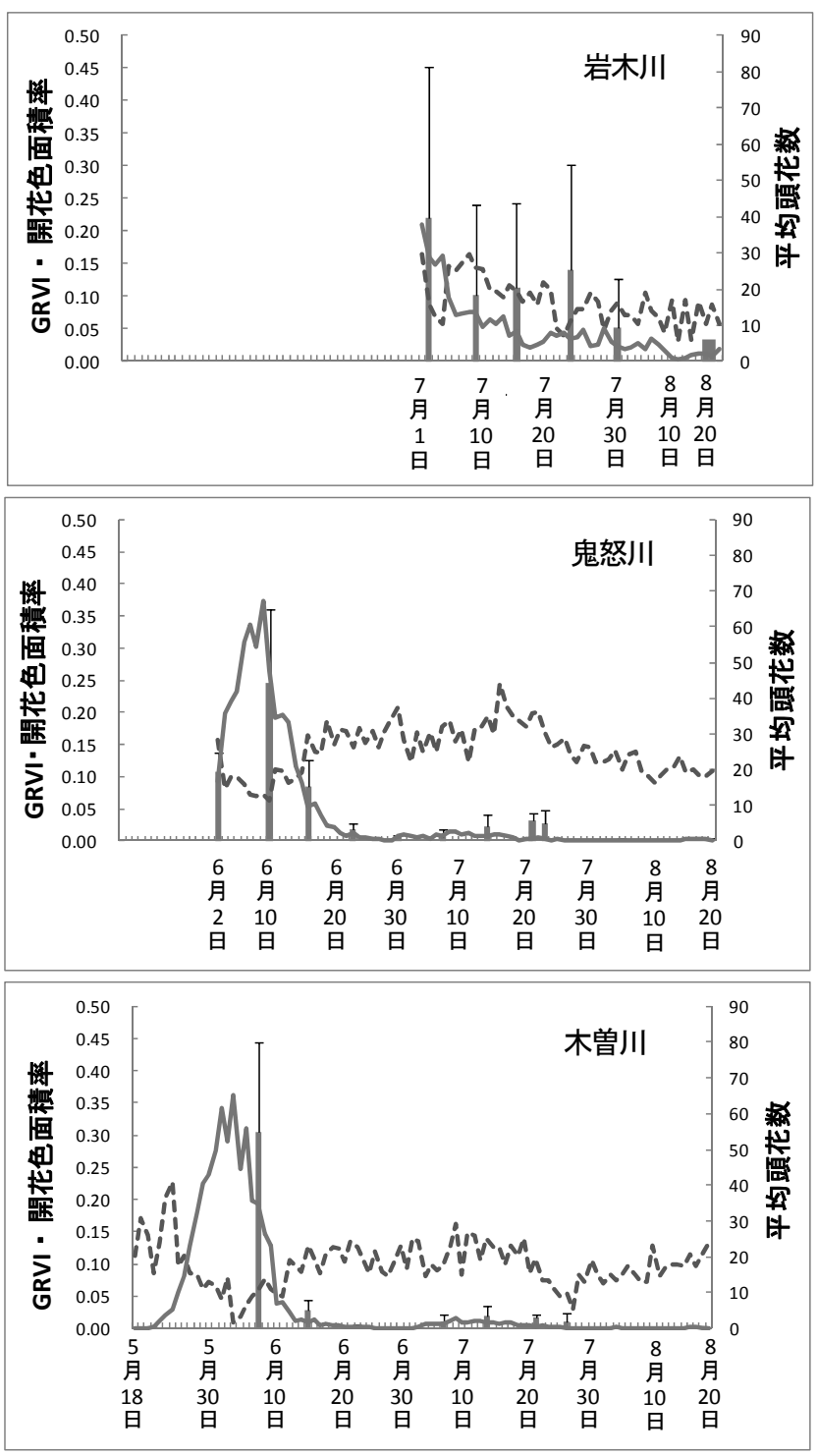

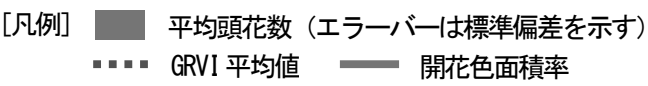

図一4 各河川における画像解析值および頭花数の推移 画像解析は, 開花期間終了に伴い開花が○となった日以降の画像を除 外して行った。解析対象画像の撮影期間は, 岩木川 7 月 1 日 8 月 28 日 (うち 8/13 26 欠測)，鬼怒川 6 月 2 日 8 月 25 日（うち 7/23〜29 欠測)，木曽川 5 月 18 日 8 月 19 日である。

表一2 頭花数を予測する一般化線形モデルのAICによる比較

\begin{tabular}{cccrr}
\hline モデル & 説明変数 & ネスト構造 & \multicolumn{1}{c}{$A I C$} & \multicolumn{1}{c}{$\Delta A I C$} \\
\hline 1 & 開花色面積率 & 河川/カメラ/開花色面積率 & 718 & 0 \\
2 & 開花色面積率 & & & \\
3 & GDVI & 河川/カメラ/GDVI & 2486 & 1768 \\
4 & GDVI & & 3184 & 2466 \\
\hline
\end{tabular}

表ー3 カメラごとのポアソン回帰分析の結果

\begin{tabular}{ccccc}
\hline カメラ & 標準回帰係数 & S.E. & Z値 & P值 \\
\hline 岩木川No.1 & 0.508 & 0.061 & 8.29 & $<0.001$ \\
岩木川No.2 & 0.308 & 0.072 & 4.29 & $<0.001$ \\
\hline 鬼怒川No.1 & 0.719 & 0.029 & 25.11 & $<0.001$ \\
鬼怒川No.2 & 0.791 & 0.033 & 24.17 & $<0.001$ \\
\hline 木曽川No.1 & 1.090 & 0.040 & 27.05 & $<0.001$ \\
木曽川No.2 & 1.134 & 0.045 & 25.02 & $<0.001$ \\
\hline
\end{tabular}

頭花数に対する開花色面積率の標準回帰係数を示している。 
ったことの 2 点が考えられる。1 点目の色調のむらについては, 非開花期であっても赤味を帯びた画像の GRVIは開花期並みに低 い值となり，逆に開花期であっても緑色味を帯びた画像は非開花 期並みに高い值になるものがみられるなど，開花量よりも画像の 全体的な色調が GRVI の值に影響寸る傾向があった。画像に色調 の違いが生じた原因としては，天候や時刻の違いによる太陽光ス ペクトルの変化や，インターバルカメラに搭載されたセンサ方式 (CMOS) 等の影響が想定されるが，これらが複合的に関与して いる可能性もある。2 点目の画像の切り出し面積に占める開花工 リアの面積割合については，開花エリア以外の大半を占めるとみ られる緑色系の色により GRVIの值が相殺されたものと考えられ る。切り出し面積をより小さくすれば, 盛花期において画像内に 占める開花エリアの面積割合は増加するが，一方で，面積を小さ くするほど写り込む開花数は少なくなることから，盛花期を過ぎ て疎らに咲く段階の開花量や開花期間を過小評価することになる。 そのため, 対象地域における開花量の推移および開花期間を把握 する上では，切り出し面積をあまり小さくすることは適当ではな い,GRVIは，一般的にNDVI では捉えることが困難とされる紅 葉・黄葉等の葉色変化の把握に用いられ, 有効性が確認されてい るが 9)，画面一面の色調を変化させるような葉色変化の把握には 有効であっても, オオキンケイギクの開花量の把握手法としては 限界があるものと考えられる。

\section{（2）インターバルカメラの設置方法}

インターバルカメラによる連続画像の撮影は，オオキンケイギ クの開花結実に関するデータを，広域かつ連続的に取得する上で 有効な手法であり，開花数の現地計測を代替できることが確認さ れた。より効率的に画像解析を行うためには，インターバルカメ ラの設置にあたり,以下のような点について留意する必要がある。 ・インターバルカメラの設置位置とオオキンケイギクの個体との 距離が接近していると，大写しになって開花面積を過大に評価 することになるため，個々の花が識別できる範囲で、できるだ け多くの個体が写り込むよう位置を調整する。

・オオキンケイギクの開花色の誤推定の原因になる黄色系統の色 （標識ロープなど）が写り込まないようにする。また，できる だけ人工構造物等の地物や背景の空などが入らないように画角 を調整すれば，画像の切り出しにかかる労力を軽減することが できる。

・葉や果実など，オオキンケイギクの花以外の植物体に光が反射 して白い色調となると, 花に光が反射した色調との差異がなく なり，開花色の誤推定の原因になるため，設置方向は昼間の反 射の強い南向きを避ける。

•USB メモリからのデータの回収等で, インターバルカメラの画 角にずれが生じないようにする。

\section{5. まとめ}

現地調査の結果から，オオキンケイギクは開花がピークとなる 時期に結実も最大となることが推察されるため，より確実に拡散 防止を図るためには，開花前もしくは開花初期までに刈り取りを 行う必要がある。図一4からは，除草適期として，鬼怒川は 5 月 下旬 6 月初旬, 木曽川は 5 月中旬 $~ 5$ 月下旬が想定される。た だし，岩木川については開花時期のデータが取得できていないこ と，また鬼怒川，木曽川についても単年度のデータであることか ら，今後も調査を継続しデータ精度を上げる必要がある。さらに 東北から九州までの広範囲にオオキンケイギクの分布が確認され ている1ことを踏まえ，対象とした 3 河川とは気象条件の異なる 地方の調査を進めていく必要がある。

謝辞:調查にあたっては、青森河川国道事務所、渡良瀬川河川事務

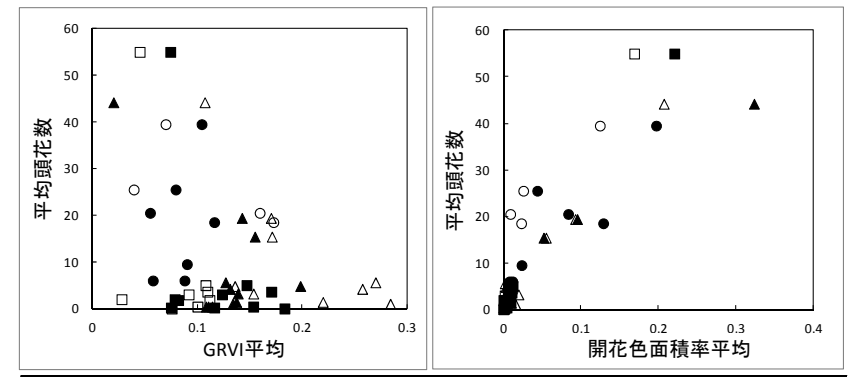

[凡例］ ○岩木川No.1カメラ ○岩木川No.2カメラ $\Delta$ 鬼怒川No.1カメラ $\triangle$ 鬼怒川No.2カメラ ロ木曽川No.1カメラ 口木曽川No.2カメラ 図-5 平均頭花数と各画像解析値との関係

所、下館河川事務所、木曽川上流河川事務所、松山河川国道事務 所に大変お世話になった。統計解析では、国土技術政策総合研究 所の上野裕介博士にご協力いただいた。以上の方々に心よりお礼 申し上げる。

\section{補注及び引用文献}

1）国土交通省水管理・国土保全局河川環境課（2012）: 平成 22 年度河川 水辺の国勢調査結果の概要 : 河川環境データベースホームページ $<$ http://mizukoku.nilim.go.jp/ksnkankyo/mizukokuweb/download/ $\mathrm{h} 22 . \mathrm{htm}>, 2012.9 .26$ 参照

2) 外来種影響・対策研究会 (2011) : 河川管理者による防除 : 河川におけ る外来種刘策の考え方とその事例【改訂版】一おもな侵略的外来種の影 響と刘策一(第 2 版) : 財団法人リバーフロント整備センター, 46-47

3）国土交通省河川砂防技術基淮維持管理編 (河川編) : 国土交通省水管理・ 国土保全局ホームページ

$<$ http://www.mlit.go.jp/river/shishin_guideline/gijutsu/gijutsukijunn/ ijikanri/index.html $>, 2012.9 .26$ 参照

4）香瀬頼子・小栗ひとみ・松江正彦 (2010) : 刈り取り管理の時期および 回数が特定外来生物オオキンケイギクに及ぼす影響と防除効果 : ランド スケープ研究 73(5)，421-426

5) 清水建美 (2003)：日本の帰化植物 : 平凡社, 500pp.

6) Takashi Motohka, Kenlo Nishida Nasahara, Hiroyuki Oguma and Satoshi Tsuchida (2010) : Applicability of Green-Red Vegetation Index for Remote Sensing of Vegetation Phenoligy, Remote Sensing 2010(2), 2369-2387

7）高田雅之・小熊宏之・井手玲子・丹羽忍 (2009) : デジタルカメラに よる湿原環境のモニタリング : 日本湿地学会第 3 回大会講演要旨, 03

8) 高山帯調査マニュアル (2012) : 環境省生物多様性センターモニタリン グサイト 1000 ホームページ

$<$ http://www.biodic.go.jp/moni1000/manual/Alpine-region_manyual. pdf>,2012.9.26 参照

9) Compton J. Tucker (1979) : Red and photographic infrared linear combinations for monitoring vegetation, Remote Sensing of Environment 8(2), 127-150

10)下野嘉子 (2010) : R を用いた一般化線形モデル (回帰係数編) : カウ ントデータを例に : 杂隹草研究 55(4), 287-294

11)久保拓弥 (2012) : データ解析のための統計モデリング入門 :一般化線 形モデル・階層ベイズモデル・MCMC : 岩波書店, 131-134

12)Akaike, H. (1973) : Information theory and an extension of the maximum likelihood principle, In Second international symposium on information theory. (eds. B. N. Petrov \& F. Csaki), Budapest, Hungary, Akademiai Kiado, 267-281

13)R Core Team (2012) : R: A language and environment for statistical computing. R Foundation for Statistical Computing, Vienna, Austria, ISBN 3-900051-07-0, <http://www.R-project.org/>,2012.12.7 参照. 